to depend upon the oxidation-reduction potential of the digest. When the potential was adjusted with varying proportions of ferri- and ferrocyanide it was apparent that with an $E_{h}$ above +0.46 v., $\mu=11,700$, below +0.42 v., $\mu=8,700$, and between +0.42 and +0.46 v., $\mu=11,700$ below and 8,700 above the critical temperature.

It is suggested that the energy of activation of the urease-urea system is determined in part by the configuration of certain essential radicals such as the sulphydryl' groups in the enzyme molecule. When such structures are in the reduced condition, $\mu=8,700$, but when oxidized, $\mu=11,700$. The change from the reduced to the oxidized form is reversible and is accompanied by this shift in temperature characteristic.

The temperature characteristic of 20,800 for soy bean urease is listed in most text-books. This value was calculated by Euler ${ }^{5}$ from the data of Van Slyke and Cullen ${ }^{6}$ and is incorrect. Recalculations indicate a value for $\mu$ of 11,700 ; this is identical with one of those obtained with Jack bean urease. It is apparent that the activation energy is independent of the source and purity of the urease, but does shift in a predictable manner with the oxidation-reduction potential of the digest.

Laboratories of Biological Engineering,

IRWIN W. STzer.

Massachusetts Institute of Technology.

Cambridge, Mass. April 13.

${ }^{1}$ Sizer, I. W., J. Cell. and Comp. Physiol., 10, 79 (1937) ; Enzymologia, 4, 215 (1938).

'Gould, B. S., and Sizer, I. W., J. Biol. Chem., 124, 269 (1938).

s Sumner, J. B., J. Biol. Chem., 69, 435 (1926).

- Hellerman, L., Perkins, M., and Clark, W. M., Proc. Nat. Acad. Sci., 19, 855 (1933).

${ }^{5}$ Euler, H., "Chemie der Enzyme", Teil 1 (1920).

'Van Slyke, D. D., and Cullen, G. E., J. Biol. Chem., 19, 141 (1914).

\section{Vitamin C Sources in Eskimo Food}

IT is the general experience among arctic explorers that when they 'live of the land', scurvy never occurs. Stefansson ${ }^{1}$, who directed attention to this fact, cured three cases of scurvy with reindeer meat.

A Norwegian scientific expedition to Angmagssalik was made during 1936-37 for the purpose of examining nutrition, metabolism, physique and health of Eskimos. The accompanying table shows the vitamin $\mathrm{C}$ content of the available food. The numbers are means of at least two observations. We used the method of Emmerie and van Eekelen ${ }^{2}$.

It must also be mentioned that 'mattaq' (epidermis of whale) which Bertelsen ${ }^{3}$ especially has pointed out as a good antiscorbutic remedy, contained $20 \mathrm{mgm}$. ascorbic acid per $100 \mathrm{gm}$. (from narwhal). In skin of young seals from the coast of Norway we found such enormous amounts as $180 \mathrm{mgm}$. per $100 \mathrm{gm}$.

It is well known that marine algæ are used as food in Japan, China, Hawaii, and some algæ are eaten on Iceland and on the coast of certain parts of Great Britain. The Eskimos eat them raw or dipped in boiling water (or broth) or with blubber oil. From this source, the Angmagssalik Eskimo get 50 per cent of their vitamin C.

The other 50 per cent is mainly obtained from organs of mammals and birds and also from fish. On an exclusive lean meat diet one gets about $25 \mathrm{mgm}$. vitamin $\mathrm{C}$ a day, even when the meat is boiled. By boiling, 50 per cent is extracted or oxidized. If the broth also is used, one gets nearly $40 \mathrm{mgm}$. a day. This agrees with the experiences of Stefansson ${ }^{1}$.

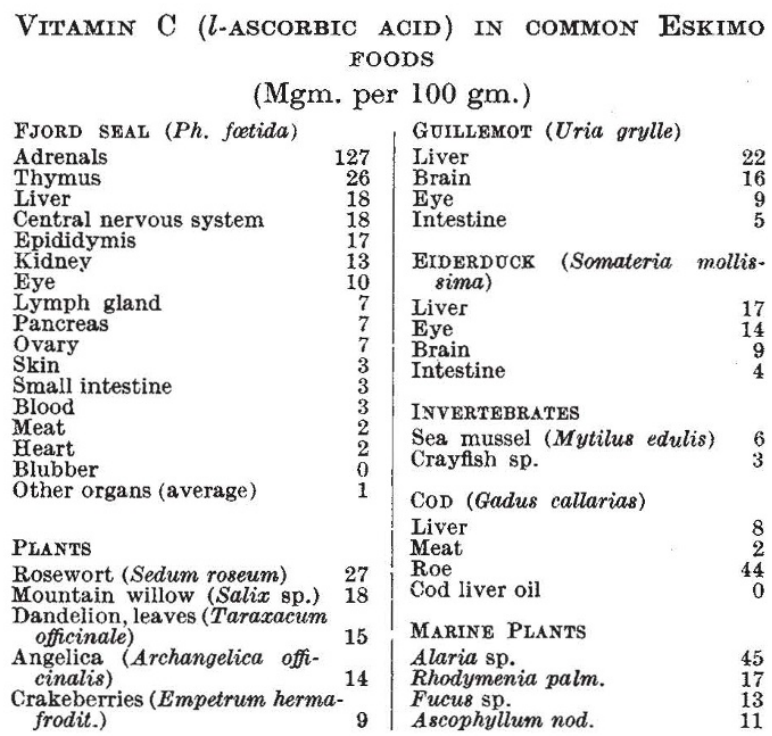

In the opinion of one of the authors (A. H.), who has been on sledging journeys of long duration in the Arctic, less than $15 \mathrm{mgm}$. ascorbic acid a day effectively prevents scurvy.

The Angmagssalik Eskimo get a daily average dose of about $40 \mathrm{mgm}$. per adult. In agreement with this finding, scurvy is unknown among Angmagssalik Eskimos.

A detailed report on the results of the work of the expedition will appear in a book this autumn.

Arne Høygaard.

Institute of Physiology,

Harald WaAge Rasmussen.

The University,

Oslo.

May 6.

'Stefansson, "Observations on Three Cases of Scurvy", J. Amer. Med. As8oc., 71, 1715-1718 (1918)

${ }^{2}$ Emmerie, A., and van Eckelen, M., "Some Critical Remarks on the Determination of Ascorbic Acid", Biochem. J., 30, 25-27 (1936).

'Bertelsen, A., "Animalske antiscorbutica i Grønland”, Hospitalstidende, 54, 537 (1911).

\section{Hormone from the Human Corpus Luteum of Early Pregnancy}

THE human corpus luteum of pregnancy is cystic up to the fourth month of pregnancy. The fluid content of the luteal follicle may be as much as 1.5 c.c.

The action of single doses of the luteal fluid $(0 \cdot 5-\mathrm{I} \cdot 0$ c.c.) is different from progesterone ('Proluton', Schering).

The luteal fluid causes deturgescence to supervene in three stages whereas progesterone produces a sudden type of deturgescence; perineal rest is attained twelve days after the injection of luteal fluid whereas with progesterone the perineum returns to rest in five and not later than seven days; the perineal rest induced by luteal fluid lasts $10-11$ days, but in the case of progesterone perineal rest is transitory and is over in twelve hours; the effects of luteal fluid are maintained for 20-21 days whereas progesterone does not act longer than seven days. 